\section{BRS Careca, BRS Fartura, BRS Duquesa, BRS Curinga, and BRS Golias: new cupuassu tree cultivars}

\section{Rafael Moysés Alves ${ }^{1}$ and Saulo Fabrício da Silva Chaves ${ }^{2^{*}}$}

\begin{abstract}
The cultivars BRS Careca, BRS Fartura, BRS Duquesa, BRS Curinga, and BRS Golias of Theobroma grandiflorum are characterized by high levels of fruit production and diverse sources of resistance to witches' broom disease. These cultivars are recommended for replacing the tree canopy of low yielding genotypes or forming new orchards.
\end{abstract}

Keywords: Theobroma grandiflorum; witches' broom disease; clonal selection; top grafting; fruit tree breeding.

\section{INTRODUCTION}

Cupuassu (or cupuaçu) [Theobroma grandiflorum (Willd ex Spreng) Schum] is a fruit tree species native to the Amazon region that is increasingly recognized as an economically viable alternative for small-scale producers in the region, especially because it adapts well to agroforestry systems (Alves et al. 2020a). However, growers lack genetic materials that combine high fruit yield with diverse resistance mechanisms against pathogens that have co-evolved with the species in wild populations (Patrocínio et al. 2017). The main pathogen is the fungus Moniliophthora perniciosa Stahel \& Philips-Mora, the etiological agent of witches' broom disease, which can have a significant impact on cupuassu production. Pioneer plantings of cupuassu that did not use selected seeds are almost unviable due to infestation by witches' broom disease, which drastically reduces yield (Benjamin et al. 2016).

Aiming at developing solutions to this problem, Embrapa Amazônia Oriental began a cupuassu breeding program in the 1980s. As a result of this program, four clonal cultivars were made available in 2002 (BRS Coari, BRS Codajás, BRS Manacapuru, and BRS Belém). In 2012, the cultivar BRS Carimbó, with an improved population genetic structure, was developed. Now, in 2020, the program is offering five new clonal cultivars: BRS Careca, BRS Duquesa, BRS Fartura, BRS Curinga, and BRS Golias. These cultivars offer high fruit yield and resistance to witches' broom disease and were primarily designed for use in replacing canopies with low yield, as well as in production of grafted seedlings to form new orchards. The aim of releasing these new clonal cultivars is to diversify the genetic base of the materials available in the region.

This study describes the agronomic and fruit traits of the cupuassu cultivars that are now available to producers and highlights their advantages in relation to the cultivars currently on the market.
Crop Breeding and Applied Biotechnology 20(4): e342920413, 2020 Brazilian Society of Plant Breeding. Printed in Brazil http://dx.doi.org/10.1590/198470332020v20n4c66 


\section{BREEDING PROCESS AND SELECTION}

To obtain the cultivars, 46 accessions of cupuassu trees in the Active Germplasm Bank (AGB) of Embrapa Amazônia Oriental were evaluated and characterized (Figure 1). Eleven mother plants were selected, and the $F_{1}$ generation was obtained after crosses between those with complementary traits. These $F_{1}$ progenies were evaluated in the field for 15 years. The plants selected from this population were cloned and two clonal evaluation trials were conducted, one using propagation by grafted seedlings, and the other using the top grafting technique (Alves et al. 2020b). After 12 years of study, the five clones with best performance were identified based on the average response of the genotypes in these two trials. The long evaluation period sought to capitalize on the peculiarities of a perennial plant, which, according to Santin et al. (2019), consists of long juvenile and reproductive cycles, great fluctuation in production over the years, differences in the period of production peak and yield longevity. All of these characteristics were taken into account to select these five clones, which constitute the set of cultivars described here.

\section{DIFFERENTIAL FEATURES}

The yield traits of the new cupuassu cultivars differed from those of the previously developed cultivars (Figure 2A) using the Scott-Knott test for comparison of genotype performance. This comparison was based on results described in the following studies: Souza et al. (2008), for clonal cultivars made available in 2008 in the state of Amazonas, Brazil, by Embrapa Amazônia Ocidental; Alves and Ferreira (2012), for BRS Carimbó, released by Embrapa Amazônia Oriental in 2012; Cruz and Alves (2002), for four clonal cultivars released by Embrapa Amazônia Oriental in 2002; and Pará (2018), for the average values reported for the state of Pará, Brazil. Although the cultivars were evaluated in different environments, they are compared here to determine, even if roughly, differences among them. Considering the yield stability phase, the average yield of the five cultivars was similar to that of BRS Carimbó, which is currently used by producers in Pará. However, the cultivars exceeded the yield of the clonal cultivars used in Amazonas by almost five ton/ha, and they produced almost twice the number of fruit as the four clonal cultivars released in 2002 in Pará. In comparison with average yield in Pará, the difference exceeded 10 ton ha-1 (Figure 2A).

This comparative advantage increases considering the main products of the cupuassu tree (pulp and seeds). The average pulp yield of the newly released genetic materials was 5.3 ton ha- ${ }^{-1}$, which represents an increase of $35 \%$ in relation to clonal cultivars in Amazonas, $16 \%$ in relation to BRS Carimbó, and $55 \%$ in relation to the first clonal cultivars developed in Pará. Regarding the average pulp production from seed orchards in Pará, this difference was $92 \%$. These results indicate that use of the new cultivars will increase the supply of cupuassu pulp to the market (Figure 2B)

The result of the new cultivars in terms of fresh seed yield showed advantages similar to the result for pulp (Figure 2C). The five cultivars produced an average of 1.9 tons of fresh seeds per hectare, representing an increase of one-half ton over the Amazonas clones. The new cultivars used in the orchards of Pará achieved an increase of $19 \%$ in relation to BRS Carimbó, and more than $46 \%$ in relation to the first clonal cultivars. Furthermore, the new cultivars showed an increase of almost $90 \%$ in comparison with the average from cultivated areas that do not use selected

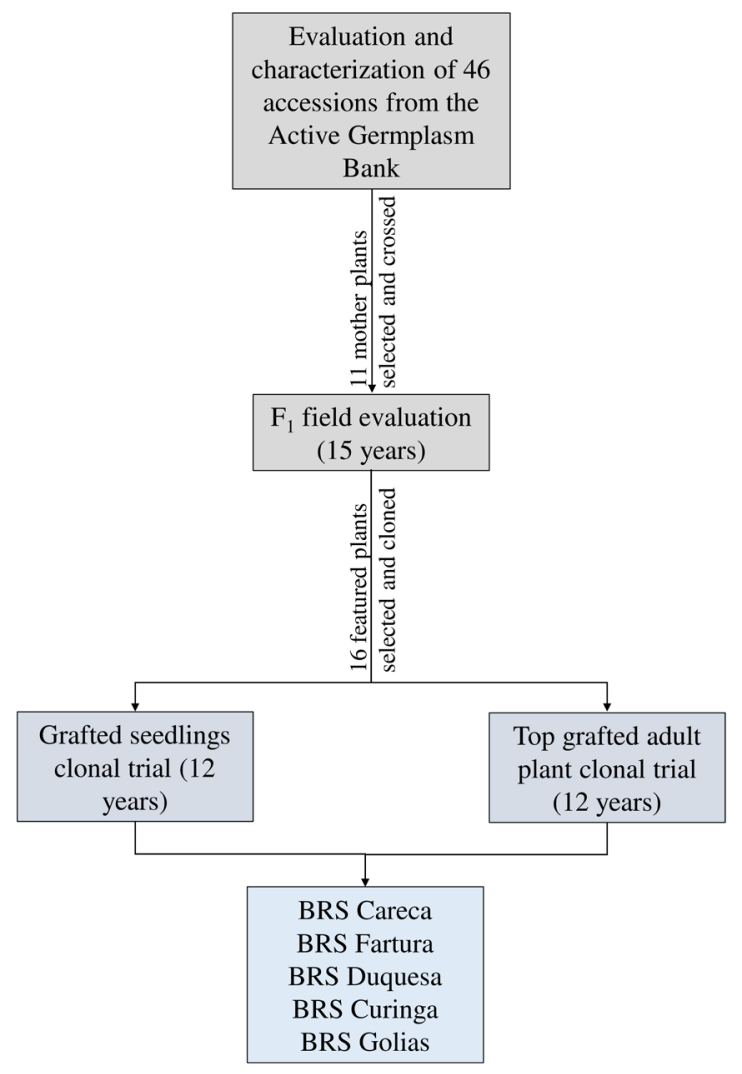

Figure 1. General outline of the breeding process that gave rise to the five new cupuassu tree cultivars. 
seeds (Figure 2C). These results indicate the dual suitability of the five cultivars, as they are effective for both pulp and seed production.

The new cultivars had physicochemical traits of the fruit pulp similar to the previously released cultivars (Figure 2D). However, their total solids content was greater than that of the BRS Carimbó cultivar, the variety most widely used in seed orchards in Pará. These results indicate that the selection of higher yielding and resistant individuals did not significantly change the quality of the fruit pulp produced.

\section{INDIVIDUAL FEATURES}

The choice of five cupuassu tree clonal cultivars was based on variability with complementarity. Therefore, each cultivar has a distinct form that differs from the others in relation to the characteristics under evaluation. When combined, these cultivars can offer a standardized technological package that simultaneously offers benefits to the producer and meets the needs of agroindustry.

The cultivars BRS Fartura and BRS Golias had the highest yield averages for fruit, pulp, and fresh seeds (Figure $3 A$ ). These two genotypes showed fruit yields of 16 ton ha-1, which is $45 \%$ higher than the yield of the seminal cultivar BRS Carimbó. It is noteworthy that only BRS Careca had fruit yield lower than BRS Carimbó, which indicates the yield potential of this set of clones. The cultivars followed a similar pattern for pulp and seed production. All showed pulp and fresh seed yield greater than or equal to the BRS Carimbó seminal cultivar, with particularly impressive results for BRS Fartura, with $60 \%$ greater yield, and BRS Golias, with $50 \%$ greater yield.

The new cultivars had low rates $(<10 \%)$ of plants exhibiting symptoms of witches' broom disease under natural infestation conditions in the field. BRS Careca, particularly, showed no symptoms throughout the 10 years of exposure in the field (Figure 3B). The cultivars with the highest yield, BRS Fartura and BRS Golias, also showed low rates of symptomatic plants (<4\%), confirming that these genetic materials successfully combine genes that positively affect both yield and disease resistance. Therefore, these clones can also be selected for use as parents in cupuassu breeding programs that aim to incorporate genes for resistance to other diseases, for example frosty pod rot disease (Moniliophthora roreri). Diversifying the source of resistance to witches' broom disease is fundamental for overcoming the great adaptation potential of the pathogen (Gramacho et al., 2016). Using five different genotypes that showed in-field resistance will provide security to producers.

The peak production period was also studied for each cultivar (Table 1). The BRS Duquesa and BRS Curinga cultivars were classified as late, as $20 \%$ of their production was concentrated in the final months of the harvest (June and July). The others were classified as regular, as most of the production occurred during the peak harvest period from February to March (Table 1). This is relevant data for forming a production schedule as it allows farmers to harvest the crop during a period with limited supply, resulting in better financial returns (Radović et al. 2020). It also facilitates the logistics of agroindustry, which can obtain raw material over a longer period of time. 
The name given to BRS Fartura (meaning "abundant" in Portuguese) is related to the large number of fruit provided by the cultivar; the average of the first harvests ( 33 fruit/plant/harvest) represents twice that generally found in cupuassu plants (Alves et al. 2020a).

Uniformity, which is essential for commercialization of fresh fruit, was observed in the size and shape of the fruit. The average genotypic value for length was 213.44 $\mathrm{mm}$, and for diameter, $117.1 \mathrm{~mm}$ (Table 1). Meanwhile, the average genotypic value for fruit weight of the five cultivars was almost $2 \mathrm{~kg}$. BRS Golias had the highest levels of pulp content. BRS Duquesa had the greatest average fruit weight of the five cultivars, in addition to the highest proportion of seeds, indicating that this genetic material is more appropriate for seed production (Table 1).

Regarding the physicochemical traits of the fruit pulp, uniformity was observed among the cultivars, with all characteristics within the quality standards established by the Brazilian Ministry of Agriculture (Ministério da Agricultura, Pecuária e Abastecimento - MAPA) (Brazil 2018). BRS Careca had fruit with comparatively higher soluble solids content and intermediate values of titratable acidity and $\mathrm{pH}$. These traits give the pulp a sweeter flavor. In contrast, the BRS Curinga and Golias cultivars had higher titratable acidity, as did the BRS Duquesa and BRS Fartura cultivars, which had lower $\mathrm{pH}$. These cultivars have traits that enable longer-term preservation of the pulp, which depends on intrinsic acidity (Table 2 ). The blend produced by mixing the pulp of all cultivars will therefore offer intermediate characteristics that meet the standards of the most demanding markets. When there are specific demands, fruit from the cultivars with the most favorable characteristics can be directed to that purpose.

\section{PROPAGATION AND FIELD ARRANGEMENT}

Propagation of these cultivars must be carried out exclusively by vegetative propagation in order to preserve

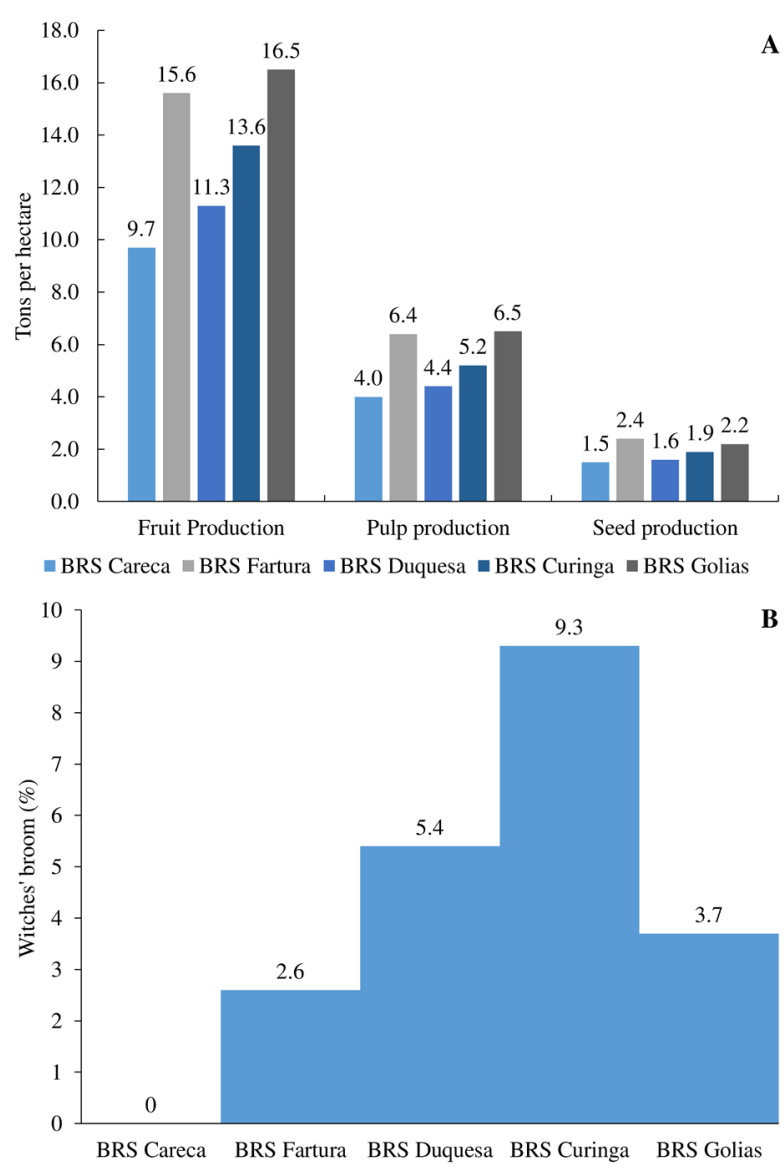

Figure 3. Individual performance of five new cupuassu tree cultivars: Average fruit, pulp, and seed production (in tons per hectare) (3A) and Percentage of plants with symptoms of witches' broom (caused by Moniliophthora perniciosa) (3B).

Table 1. Average genotypic values for agronomic traits of the plant and physical traits of the fruit, for five new cupuassu tree cultivars

\begin{tabular}{|c|c|c|c|c|c|}
\hline \multirow[b]{2}{*}{ Trait } & \multicolumn{5}{|c|}{ Cultivar } \\
\hline & BRS Careca & BRS Fartura & BRS Duquesa & BRS Curinga & BRS Golias \\
\hline \multicolumn{6}{|c|}{ Yield aspects } \\
\hline Productive period & Regular & Regular & Late & Late & Regular \\
\hline Number of fruit per plant $(S A=0.47)^{1}$ & 19.5 & 28.3 & 19.2 & 22.8 & 25.9 \\
\hline \multicolumn{6}{|c|}{ Fruit physical traits } \\
\hline Fruit length $(\mathrm{mm})(\mathrm{SA}=0.90)$ & 194.1 & 214.0 & 233.8 & 208.1 & 217.2 \\
\hline Peel percentage (\%) $(\mathrm{SA}=0.91)$ & 51,0 & 50,7 & 46,4 & 49.6 & 48.4 \\
\hline Pulp percentage (\%) (SA =0.96) & 35.9 & 36.2 & 40.9 & 39.5 & 41.3 \\
\hline Fresh seed percentage (\%) $(\mathrm{SA}=0.93)$ & 12.2 & 11.1 & 10.8 & 11.9 & 8.7 \\
\hline Number of seeds per fruit ( $S A=0.22$ ) & 32.3 & 32.4 & 32.7 & 32.5 & 32.2 \\
\hline
\end{tabular}

${ }^{1}$ SA: Selective Accuracy 
BRS Careca, BRS Fartura, BRS Duquesa, BRS Curinga, and BRS Golias: new cupuassu tree cultivars

Table 2. Average genotypic values for physicochemical traits of the fruit pulp, for five new cupuassu tree cultivars

\begin{tabular}{|c|c|c|c|c|c|}
\hline \multirow[b]{2}{*}{ Trait } & \multicolumn{5}{|c|}{ Cultivar } \\
\hline & BRS Careca & BRS Fartura & BRS Duquesa & BRS Curinga & BRS Golias \\
\hline Ash (\%) $(S A=0.77)^{1}$ & 2.4 & 3.2 & 3.49 & 3.2 & 3.3 \\
\hline Proteins $(\%)(S A=0.79)$ & 6.9 & 7.4 & 6.9 & 7.0 & 7.6 \\
\hline Reducing sugar (g glucose $100 \mathrm{~g}^{-1}$ pulp) $(\mathrm{SA}=0.79$ ) & 7.7 & 7.3 & 7.5 & 7.7 & 6.4 \\
\hline Vitamin C (mg $100 \mathrm{~g}^{-1}$ pulp) $(\mathrm{SA}=0.95)$ & 21.1 & 16.5 & 25.3 & 28.3 & 15.9 \\
\hline Total soluble solids ( ${ }^{\circ}$ Brix) $(\mathrm{SA}=0.50)$ & 14.6 & 13.9 & 14.2 & 14.3 & 14.2 \\
\hline
\end{tabular}

${ }^{1} \mathrm{SA}:$ Selective Accuracy

the individual qualities of each cultivar. The segregation that may result from crossing clones in seed production limits our ability to predict the performance of their descendants and, therefore, to recommend resulting progenies.

Due to the self-incompatibility of cupuassu and the clonal propagation of the cultivars, the full set of five clones must be used to develop a seed orchard. The plants must be arranged in an organized manner in the field so that each clone is flanked by one of the other four clones on the four quadrants. That way, pollination efficiency is maximized, providing conditions necessary for plants to achieve full performance (Alves et al. 2020b).

\section{AVAILABILITY}

The cultivars are registered in MAPA under codes 28732, 28733, 28735, 28741, and 28744, for BRS Careca, BRS Fartura, BRS Duquesa, BRS Curinga, and BRS Golias, respectively. Cultivation recommendations and instructions are available at the main offices of Embrapa Amazônia Oriental in Belém and Tomé-Açu, Pará, Brazil.

\section{REFERENCES}

Alves RM and Ferreira FN (2012) BRS Carimbó - A nova cultivar de cupuaçuzeiro da Embrapa Amazônia Oriental. Embrapa Amazônia Oriental, Belém, 8p. (Comunicado técnico, 232).

Alves RM, Chaves SFS and Bastos AJR (2020a) Viability of the use of African mahogany with cupuassu tree in agroforestry system (AFS). Revista Árvore 44: e4407.

Alves RM, Chaves SFS, Oliveira RP, Pedroza Neto, JL and Sebbenn AM (2020b) Canopy replacement used in the evaluation of cupuassu tree genotypes in the state of Pará. Revista Brasileira de Fruticultura 42: e597.

Benjamin CS, Luz ED, Santos WO and Pires JL (2016) Cacao families and parents selected as resistant to natural infection of Moniliophthora perniciosa. Crop Breeding and Applied Biotechnology 16: 141-146.

Brasil (2018) Ministério da Agricultura e do Abastecimento. Resolve: Fica estabelecida em todo o território nacional a complementação dos Padrões de Identidade e Qualidade de Suco e Polpa de Fruta, na forma desta Instrução Normativa. Diário Oficial [da] União, Brasília. (Instrução Normativa, 49).

Cruz ED and Alves RM (2002) Clones de cupuaçuzeiro tolerante a vassourade-bruxa. Embrapa Amazônia Oriental, Belém, 2p. (Folder Técnico).
Gramacho KP, Luz EDMN, Silva FS, Lopes UV, Pires JL and Pereira L (2016) Pathogenic variability of Moniliophthora perniciosa in three agroecological zones of the cacao region of Bahia, Brazil. Crop Breeding and Applied Biotechnology 16: 7-13.

Pará - Secretaria de Estado de Desenvolvimento Agropecuário e da Pesca (2018) Indicadores Agropecuários. Available at <http://www.sedap. pa.gov.br/content/cupua\%C3\%A7u>. Accessed on July 14, 2020.

Patrocínio NGRB, Ceresini PC, Gomes LIS, Resende MLV, Mizubuti ESG and Gramacho KP (2017) Population structure and migration of the witches' broom pathogen Moniliophthora perniciosa from cacao and cultivated and wild solanaceous hosts in southeastern Brazil. Plant Pathology 66: 900-911.

Radović A, Rakonjac V, Vico G, Đorđević B, Đurović D, Bakić I and Nikolić D (2020) Phenological characteristics and yield potential of some lateripening peach hybrids. Crop Breeding and Applied Biotechnology 20: e33102045.

Santin MR, Coelho MC, Sayd RM, Peixoto JR and Amabile RF (2019) Yield, maturation cycle, and estimates of genetic parameters of Robusta coffee genotypes under irrigation in the Cerrado. Crop breeding and Applied Biotechnology 19: 387-394.

Souza AGC, Souza MG, Sousa NR, Fascin RB and Silva SEL (2008) Clones de cupuaçuzeiro para o Amazonas. Embrapa Amazônia Ocidental, Manaus, 5p. (Comunicado Técnico, 67). 